\title{
Szabó Diána
}

Debreceni Egyetem, Humán Tudományok Doktori Iskola

\section{Látlelet a pedagógusok befogadó neveléshez-oktatáshoz való hozzáállásáról}

A tanulmány a Közép-magyarországi régióban, állami fenntartású általános- vagy középiskolában dolgozó pedagógusok $(n=315)$ körében lefolytatott attitúdvizsgálatot mutat be. Célja annak a kérdésnek az alapos körüljárása volt, hogy a pedagógusok mennyire befogadóak a SNI tanulókkal szemben, hogyan viszonyulnak hozzájuk, mennyire szolidárisak velük, illetve milyenek az integrációról alkotott elképzeléseik. A vizsgálat eredményeképp a pedagógusok negativ attitúdjét befolyásoló tényezók összehasonlitására került sor demográfiai, objektív és szubjektív háttérváltozókkal.

\section{Bevezetés}

A magyar köznevelési rendszer müködését nemzetközi és hazai szinten is számos kritika éri, amelyek közül a három leggyakrabban emlegetett tényező a következő: (1) az SNI tanulók iskolai esélyei jelentősen rosszabbak más tanulókhoz képest (OECD, 2012); (2) nagyok az iskolák közti különbségek (Báthory, 1998); (3) az oktatási rendszerünknek erős a társadalmi szelekciót erősítő funkciója (Csapó, 2002; OECD, 2012; Halász, 2012). Ezen kritikai észrevételekhez is kapcsolódva nemzetközi oktatáspolitikai célként fogalmazódott meg a fogyatékossággal élő személyek társadalmi beilleszkedésének elősegítése (Commission, 2011), továbbá a velük szemben kialakult elöítéletesség teljes felszámolása (European Report, 2011), és az SNI tanulók számára a méltányosabb köznevelési rendszer megteremtése.

Az SNI tanulók száma évről évre folyamatosan nő, a speciális oktatási formában nevelt SNI tanulók száma 34 ezer fö $(K S H, 2013)$. Nemzetközi viszonylatban is a SNI tanulók nevelésében, oktatásában már hosszú ideje a befogadó (inkluzív) szemlélet terjed, azonban elterjedésének számos akadályozó tényezője van. A befogadó szemlélet kihívásai közt leggyakrabban a következőket említik: (1) az alacsony felkészülési szintet (az intézményi befogadás, és az oktatásra való felkészülés vonatkozásában) (Torda és Perlusz, 2010; Csányi, 1993); (2) a befogadó intézményi környezet hiányát (Csányi, 2000; Gaál, 2000; Fischer, 2009); (3) a támogató, befogadó társadalmi attitüd hiányát (Könczei, 2009); (4) az elöítéletességet, diszkriminációt (esetünkben a többségi intézmény pedagógusainak elöítéletes hozzáállása, negatív attitüdje) (Erős és Gárdos, 2007; Murányi, 2006; Takács, 2007; Billédi, 2008; Laki, 2010). Hazai és nemzetközi kutatási eredmények igazolták, hogy az együttnevelés sikeressége a tanórán dől el, és ebben a 
folyamatban a befogadó pedagógus attitüdje, szakmai hozzáállása mérvadó (Némethné, 2009; Réti és Csányi, 1997). Az SNI tanulók integrációjának sikeressége szempontjából egy alapvető tényező a befogadó pedagógusok elfogadó hozzáállása az SNI tanulókhoz és az integrált neveléshez (Szegö, 2008; Rye, 1993; Leyers és Abrams, 1983).

Jelen tanulmányban, a Közép-magyarországi régióban, állami fenntartású általánosvagy középiskolában dolgozó pedagógusok körében lefolytatott attitüdvizsgálat kerül elemzésre. A vizsgálat célja, a pedagógusoknak az SNI tanulók integrált nevelésével kapcsolatos negatív attitüdjét befolyásoló tényezők feltárása volt. Az iskolai integráció, másrészt a későbbi társadalmi beilleszkedés szempontjából is kiemelkedő kérdés, hogy a pedagógusok mennyire befogadóak az SNI tanulókkal szemben, hogyan viszonyulnak hozzájuk, mennyire szolidárisak velük, illetve milyenek az integrációról alkotott elképzeléseik. A pedagógusok negatív attitüdjét befolyásoló objektív és szubjektív tényezők feltárása hozzájárulhat a pedagógusok befogadó szemléletének javításához. Az eredmények a gyakorlati hasznosíthatóság szempontjából is nagyfokú érdeklődésre tarthatnak számot.

\section{Vizsgálati előzmények}

A pedagógusok előítéletes hozzáállásának, negatív attitűdjének hátterében álló oki tényezők feltárása előtt fontos tisztázni az attitüd meghatározását. Az attitüd nem más, mint pozitív vagy negatív viszonyulás tárgyak, személyek, csoportok, helyzetek, vagy a környezet bármely mozzanata iránt. Atkinson (2003) szerint három eleme van: kognitív (ismereti), affektív (érzelmi) és konatív (viselkedési) összetevő. A kognitív összetevő az egyénnek az attitüd tárgyával kapcsolatos ismereteire, az affektív komponens pedig az érzelmi viszonyulására vonatkozik. A konatív elem vizsgálata során a személy nyilatkozik az attitüdtárggyal kapcsolatos lehetséges viselkedési megnyilvánulásáról.

Tudományterülettöl függetlenül egyetértés mutatkozik abban a tekintetben, hogy az attitűd egy elvont fogalom, amely közvetlenül nem mérhető. Az attitüdmérés módszerei különbözőek, de a legtöbb módszer az attitüdök egydimenziós elgondolásán alapul, vagyis az attitüdök mérhetőek az attitüdtárgyról alkotott vélemény szempontjából (Thurstone, 1931; Likert, 1932). A fogyatékosokkal szembeni attitüdöt leggyakrabban attitüdskálás méréssel - pl. ATDP, ORM, SACIE - (Szegö, 2008; Forlin, Loreman, Sharma és Earle, 2007; Petö és Czeglédi, 2012) vagy kvalitatív interjús vizsgálatokkal végzik (Holloway, 2001; Fuller, Bradley és Healey, 2004).

A pedagógusoknak az integrált neveléssel, illetve az SNI tanulókkal kapcsolatos attitüdjét feltérképező vizsgálatokat a kutatás célja szerint három csoportra lehet osztani: (1) az integrációval szembeni attitüdvizsgálatok; (2) az SNI tanulókkal, hallgatókkal szembeni attitüdvizsgálatok; (3) az integrált neveléssel, oktatással kapcsolatos, valamint az SNI tanulókkal, illetve fogyatékossággal élő személyekkel kapcsolatos attitűdvizsgálatok.

Az integrációval, az integrált neveléssel-oktatással kapcsolatos attitüdvizsgálatok (ld. Réti és Csányi, 1998; Perlusz, 2008; Torda és Perlusz, 2010; Meijer, 2001; Papp, 2002; Fischer, 2009; Némethné, 2009; Szekeres, 2012; Petö és Ceglédi, 2012) eredményei megegyeznek abban, hogy az integrált oktatásban szerzett tapasztalat összefügg az integráció iránti elfogadóbb attitüddel. Korábbi kutatások eredményei azt támasztják alá, hogy azok a pedagógusok, akik gyakorlati tapasztalatot szereztek egy-egy SNI tanuló nevelésében, oktatásában, inkább vállalkoznának az integrált nevelés, oktatás feladatára (Perlusz, 2008; Leyers és Abrams, 1983). A szakirodalom szerint ennek hátterében az áll, hogy ezek a pedagógusok tisztában vannak szakmai kompetenciájukkal, és pedagógiai eszköztáruk alkalmasnak bizonyult az SNI tanulók nevelésére, oktatására (Torda és Perlusz, 2010; Perlusz, 2008; Réti, 1996). Ezt a tézist alátámasztja több vizsgálat megállapí- 
tása (Torda és Perlusz, 2010; Csányi, 1993), amely szerint a pedagógusok integrált neveléssel kapcsolatos elutasítása, negatív attitüdje hátterében a szakmai felkészületlenség áll. Leyers és Abrams (1983) vizsgálatai alátámasztották, hogy az integrációs képzéseken részt vett pedagógusok pozitívabb attitüddel rendelkeznek. Hazai vizsgálatok azt mutatták, hogy az integrált neveléssel kapcsolatos tájékozottság mértéke egyenes arányban áll a pályán eltöltött évek számával, ami arra is utalhat, hogy a befogadó pedagógusok gyakorlati tapasztalataik alapján szereztek ismereteket az integrált nevelésről (Torda és Perlusz, 2010). Az integrációs tapasztalat hatását vizsgáló kutatások általános megállapítása, hogy a tapasztalatszerzés az attitüdváltozás alapja lehet (Strobe és Jonas, 1995; Torda és Perlusz, 2010; Perlusz, 2008). Némethné (2009) a Nyugat-Dunántúlon 170 általános és középiskolában dolgozó pedagógus körében készített vizsgálatot, amelyben leginkább az integrált neveléssel, oktatással kapcsolatos attitüdre, illetve a tanórán fellépő nehézségekre és ezek leküzdésére fókuszált. Némethné (2009) kutatásának eredménye szerint a megkérdezettek több mint kétharmada elvileg támogatja az integrált nevelést. Pető és Ceglédi (2012) a pedagógusok osztálytermi inklúziójával kapcsolatos elfogadását egy nemzetközi szinten már elfogadott SACIE skála próbavizsgálatával tesztelték. Kutatási eredményeik alátámasztották, hogy a pozitív attitüd szoros összefüggést mutat azzal, hogy a tanár a pedagógiai tanulmányai során kapott-e ismereteket a sérüléstípusokról (Sharma, Forling és Lorman, 2008).

\section{Az SNI tanulókkal, hallgatókkal szembeni attitüd vizsgálatok (Id. Illyés és Méhes, 1975; Pongrácz, 2013; Újfalussy, 2014; Pusztai és Szabó, 2014)}

Valamennyi vizsgálat közös pontja, hogy az attitüdök hátterében meghúzódó okokat összetett kérdésként kezeli, és az attitüd egyes összetevőinek vonatkozásában is vizsgálódik. Illyés és Mérei (1975) az elfogadás és elutasítás dimenziói mentén vizsgálta az ép emberek fogyatékos személyekhez füződő társas kapcsolataiban az attitüdöket. Megállapításaik között szerepelt, hogy a társadalmi beilleszkedés mértéke nemcsak a fogyatékosság minőségétől és fokától függ, hanem a fogyatékossággal élö emberrel szemben tanúsított társadalmi reakcióktól is. Pongrácz (2013) a többségi általános iskolások SNI gyermekekkel szembeni attitűdjét vizsgálta, Magyarországon először a „Chedoke-McMaster fogyatékos gyermekek iránti attitüdöt vizsgáló skála" (Chedoke-McMaster Attitudes Towards Children with Handicaps Scale) és a Harter-féle „Globális önértékelési skála" (Global Self Worth Subscale) tesztelésével. Pilot vizsgálatában a nemzetközi eredményekhez hasonlóan pozitívabb attitüdöt talált a következő háttérváltozók esetében: a fiatalabb életkor, a szorosabb kapcsolat a fogyatékossággal élö gyermekkel, a jobb életminőség, a magasabb önértékelés. A válaszadók neme és a fogyatékossággal élő emberekkel kapcsolatos előzetes ismeretek megléte vonatkozásában azt találta, hogy nem befolyásolják a fogyatékossággal élö társakkal kapcsolatos attitüdöket. Pusztai és Szabó (2014) egy nemzetközi kutatás keretében vizsgálta Magyarország, Románia és Ukrajna felsőoktatási régiójába tanuló hallgatók viszonyulását fogyatékossággal élö hallgatótársaikhoz $(\mathrm{N}=2728)$. Vizsgálatuk során az elfogadó attitüd összetettsége okán a társadalmi és az egyéni tényezők feltárására és ezek kapcsolatára helyezték a hangsúlyt. Vizsgálati eredményeik alátámasztották, hogy a kisebbségi csoportokhoz tartozás növelte a fogyatékossággal élö hallgatók iránt érzett szolidaritást. A társadalmistátusz-mutatók közül a szülői iskolázottság, az állandó lakóhely településtípusa, valamint a család anyagi helyzete vonatkozásában vizsgálódtak, de nem találtak szignifikáns összefüggést a vizsgált dimenziókban, tehát egyik mutató sem befolyásolta a fogyatékossággal élő hallgatókkal szembeni elfogadó attitüdöt. 


\section{Az integrált neveléssel, oktatással kapcsolatos és az SNI tanulókkal, illetve a fogyatékossággal élő személyekkel kapcsolatos attitüdvizsgálatok (Szegö, 2008; Újfalussy, 2014)}

Szegő (2008) vizsgálatában a pedagógusoknak a látássérült, hallássérült, illetve mozgássérült tanulók integrációjával kapcsolatos attitüdjét vizsgálta $(\mathrm{n}=108)$. Vizsgálatában összefüggést talált a fogyatékossággal élő személyekkel való személyes kapcsolat és a fogyatékosokkal mint csoporttal, valamint az integrált nevelésükkel kapcsolatos attitüdök között. Az integrált oktatásban szerzett tapasztalat összefüggést mutatott az integráció iránti elfogadóbb attitűddel, ez azonban a csoport nagyobb elfogadásában nem jelentkezett. Újfalussy (2014) a felsőoktatási hallgatók attitűdjét az ismeret, a viselkedés és az elfogadás dimenziói mentén vizsgálta. Feltételezte, hogy az attitüd három összetevője összefügg egymással, vagyis a kognitív konzisztencia lesz jellemző a hallgatók válaszaira, azonban ezt az eredmények nem támasztották alá. Vizsgálatai szerint a sérült emberekről való vélekedés, tudás nem feltétlenül van hatással az elfogadásra, az érzelmeinkre. Az attitüd érzelmi összetevője jobban meghatározza a sérült emberekről kialakult képünket, mint az ismereteink, tapasztalataink.

A pedagógusok attitüdjének témakörében vizsgálódó kutatásokon áttekintve elmondható, hogy a vizsgálatok kis elemszámú mintán történtek. Hazánkban kevés a régiós lefedettségü attitüd vizsgálat, a Közép-magyarországi régió vonatkozásában még nem születtek vizsgálatok a témában. A korábbi tudományos munkák között elvétve találni többváltozós elemzéseket, azonban közülük csak néhány fókuszált a vizsgálatában az attitűd mindhárom összetevőjére, a kognitív összetevő, például a speciális ismeret oldaláról még nem közelítették meg a kérdést. Az alábbiakban bemutatásra kerülő kutatás során mindezeket a hiányokat kívánjuk pótolni.

\section{A pilot vizsgálat részletei}

\section{Módszerek, eszközök}

A pedagógusok negatív attitüdjét befolyásoló tényezők vizsgálatát az SNI tanulókkal, illetve az integrált nevelésükkel, oktatásukkal kapcsolatban kérdöíves technikával, attitüdvizsgálattal végeztük. A vizsgálat során alkalmazott módszerek és eszközök a következők voltak: dokumentum-elemzés (2013. évi intézményfejlesztési tervek), valamint az általunk készített és önkitöltős kérdöíves vizsgálat.

A vizsgálatban alkalmazott eszköz saját készítésű kérdőív ${ }^{1}$, amelyhez a Szegő (2008) által az amerikai szakirodalomból átvett két attitüdkérdőív², illetve Horváthné (2006) saját készítésű kérdőíve adta a kiindulási alapot. A kérdőív felépítését tekintve három részből épül fel. Az első részben (az 1-9. kérdésig) személyes adatokra, majd a második részben (a 10-17. kérdésig) az általános, illetve a fogyatékos személyekkel való kapcsolatra vonatkozó kérdések (értékrend, fogyatékossággal élő személyekkel kapcsolatos ismeretek stb.) találhatóak. Eddig még nem vizsgált új elemként jelenik meg a kérdöívben a társadalmi háttérváltozók közül a családi állapot és az értékrend. A kérdőív második része a fogyatékosokkal szembeni ún. általános attitüdöket vizsgálja, azaz a fogyatékossággal élő személyekkel mint egységes csoporttal szembeni attitüdöket. Ezután következnek a harmadik részben (a 18. kérdéstől) az ún. szervezetszociológiai kérdések, érintem a SNI tanulók tanításával szerzett tapasztalatok kérdés körét, továbbá a SNI tanulók integrált nevelése, oktatása során fellépő problémákat. A kérdések szerkesztése során törekedtem arra, hogy elkülöníthetőek legyen a válaszok, a válaszadók fogadó (integráló) és a befogadó (inkluzív) szemlélete a pedagógus és a nevelőtestület 
feltételezett véleménye oldaláról is. A harmadik részben találhatóak tehát az SNI tanulók integrált oktatásával kapcsolatos attitüdkérdések, amelyek között fellelhetőek viselkedési szándékot felmérő kérdések is, az integráció témakörében releváns viselkedésekkel kapcsolatosan (pl. „Vállalná-e SNI tanulók tanítását?”; „Elmenne-e a témával kapcsolatos továbbképzésre?"). A válaszadás az attitüdskálákkal megegyezően, ötfokú skálán történt. A pedagógusok befogadó attitüdjét a SNI tanulókkal és együttnevelésükkel kapcsolatban a következő dimenziók mentén értelmeztem: (1) szolidaritás; (2) együttmüködés; (3) szakmai kompetencia, tájékozottság; (4) elfogadás, elöítéletesség; (5) szakmai nyitottság, megújulásra készség. A kérdőív zárt kérdéseket, illetve megállapításokat tartalmazott (Horváth, 2004).

\section{Minta és adatfelvétel}

A kérdőíves adatfelvételre 2014. augusztus és október között került sor, a Közép-magyarországi régióban található állami fenntartásban lévő köznevelési intézményekben (általános- és középiskolákban). A kutatás középpontjában a pedagógusok elöítéletes attitüdjét befolyásoló demográfiai háttérváltozók, objektív és szubjektív faktorok vizsgálata állt. A kérdőívben előforduló változó csoportok a következők: (1) értékorientációval kapcsolatos változók; (2) egyéni szocioökonómiai változók: nem, életkor, iskolai végzettség, pályán ténylegesen eltöltött évek száma, integrált oktatásban eltöltött évek száma, milyen szakon végzett, milyen tárgyat tanít, ismeret, tapasztalat; (3) szervezetszociológiai változók: szervezeti bizalom, gyógypedagógussal való együttműködés, tantestületi légkör, iskola társadalmi megítélése.

A mintába a Közép-magyarországi régió állami fenntartású alap- és középfokú intézményeinek pedagógusai önkéntes alapon kerültek be. A kérdöíveket postai úton, a tankerületek beleegyezésével a köznevelési intézmények igazgatóin keresztül juttattuk el a vizsgálatban részt venni kívánó személyekhez. A minta elemszámát a köznevelési fejlesztési tervek dokumentumelemzése segítségével határoztuk meg, a dokumentumok alapján a Közép-magyarországi régióban összesen 26101 pedagógus dolgozik. $(\mathrm{N}=$ 26 101). A vizsgálati személyek általános iskolai, szakközépiskolai és gimnáziumi pedagógusok voltak. Az iskolák kiválasztásának az volt a szempontja, hogy legyen közöttük olyan, mindhárom iskolatípust tekintve, ahol van integrált oktatás, és olyan is, ahol nincs, ezzel biztosítva, hogy legyenek integrációs tapasztalattal rendelkező és nem rendelkező tanárok is. A kérdőívet 36 köznevelési intézményböl 315 pedagógus töltötte ki, küldte meg $(\mathrm{n}=315)$. Átlagosan minden intézményből 1 férfi töltött ki kérdőívet, ők teszik ki a vizsgálatban részt vevők 10 százalékát. Nem meglepő a minta női felülreprezentáltsága, hiszen a pedagógusi köztudottan egy elnőiesedett pálya. Nemzetközi viszonylatban is számos országra jellemző a pálya elnőiesedése, azonban nálunk más országokhoz viszonyítva még nagyobb arányban dolgoznak inkább nők a pályán, mint férfiak $(O E C D, 2012){ }^{3}$

Az adatfelvétel után bevitt és megtisztított adatok feldolgozása SPSS 20.0 statisztikai program használatával történt (Falus és Ollé, 2000). Az adatfeldolgozás során a leíró statisztikák mellett két- és többváltozós összefüggés-vizsgálatokat végeztünk, melyek során a kereszttábla-, variancia-, főkomponens-elemzést és a lineáris regresszió módszerét alkalmaztuk. Az adatok statisztikai elemzése során a negatív attitüd főkomponens létrehozása után egyutas varianciaanalízissel néztük meg, hogy e dimenziók mentén milyen különbségek vannak a negatív attitüd tényezői és a pedagógusok munkahelyének településtípusa között. Ezt követően a negatív attitüd fökomponens és a legfontosabb társadalmi háttérváltozók hatását lineáris regresszióval vizsgáltuk meg. A modellekbe a következő magyarázó változókat emeltük be: nem; tanítási éveinek száma; életkor; személyes kapcsolat; speciális szakismeret; integrál-e; településtípus; intézménytípus. 


\section{Vizsgálati kérdések, hipotézisek}

Az első hipotézis arra vonatkozik, hogy (1) a befogadó pedagógusok nem rendelkeznek kellő ismeretekkel a fogyatékosságról és az SNI tanulók neveléséről-oktatásáról (Strobe és Jonas, 1995; Perlusz és Torda, 2010; Perlusz, 2008; Némethné, 2009). Feltételezzük, hogy azok a befogadó pedagógusok, akik tapasztalattal rendelkeznek az SNI tanulók neveléséről-oktatásáról, pozitívabb attitüddel rendelkeznek az SNI tanulókkal kapcsolatban (Szegö, 2008; Miles, 2000). Feltételeztük továbbá, hogy az általános iskolában dolgozó pedagógusok szolidárisabbak a SNI tanulókkal szemben, mint a középiskolában dolgozó pedagógusok.

A befogadó nevelés és a településtípus közti kapcsolatról úgy gondoltuk, hogy (2) a Pest megyében dolgozó befogadó pedagógusok elfogadóbban az SNI tanulókkal, mint a fóvárosban dolgozó befogadó pedagógusok.

Azzal kapcsolatban, hogy a pedagógusok mely sérüléstípusba tartozó SNI tanulóval szemben rendelkeznek a leginkább negatív attitüddel, azt feltételeztük, hogy (3) az értelmileg akadályozott tanulókkal szemben a legkevésbé befogadóak az integráló intézményben dolgozó pedagógusok (Illyés és Erdösi, 1986).

Végső hipotézisünk során feltételeztük, hogy (4) a negatív attitüd társadalmi nemtől független, és befolyásolják az ismeretek (Tavares, 2011; Pongrácz, 2013).

\section{Eredmények}

\section{Demográfiai háttérváltozók}

A pedagógusok demográfiai mutatói és a SNI tanulók neveléséhez-oktatásához való viszonya vonatkozásában a társadalmi nem, az életkor, az iskolai végzettség, az intézménytípus és a településtípus hatását ellenőriztük.

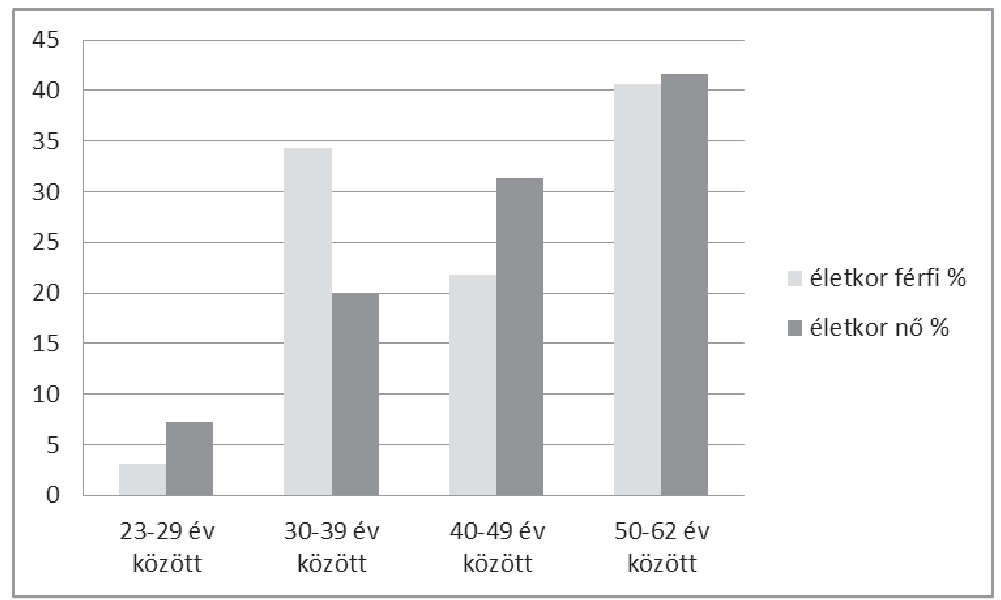

1. ábra. A válaszadók társadalmi nem és életkor szerinti százalékos megoszlása ( $n=315)$

A válaszadókat életkoruk szerint 4 kategóriára osztottuk. A legtöbb válaszadó a nők és a férfiak közül egyaránt az 50-62 év közötti életkori kategóriába tartozik. A legkevesebb válaszadó pedig a 23 és 29 év közöttiek korcsoportjában volt. Jelen vizsgálat eredményei alapján a vizsgálatban részt vett pedagógusok nagy része 40 év feletti. 
A kutatásban részt vett pedagógusok legmagasabb iskolai végzettségének százalékos megoszlása azt mutatja, hogy a válaszadók több mint 60 százaléka alapképzéses diplomával rendelkezett, tanítóképzőt, vagy tanárképző főiskolát végzett. Egyetemi végzettséggel a válaszadók 17 százaléka rendelkezik. A kapott vizsgálati eredményt magyarázza, hogy a kutatásban részt vevő intézmények közül a legtöbb általános iskola volt. Alap vagy mesterképzéses diplomával és szakvizsgával a válaszadók 22 százaléka rendelkezik.

\section{Integrációban való részvétel hatása a befogadó szemléletre}

A pedagógusokra vonatkozó demográfiai háttérváltozók közül két dimenzióban mutatkozott szignifikáns összefüggés: a válaszadók integrációban való részvétele és az intézménytípus, valamint a pedagógusok nézetei a befogadó szemléletről és a településtípus között.

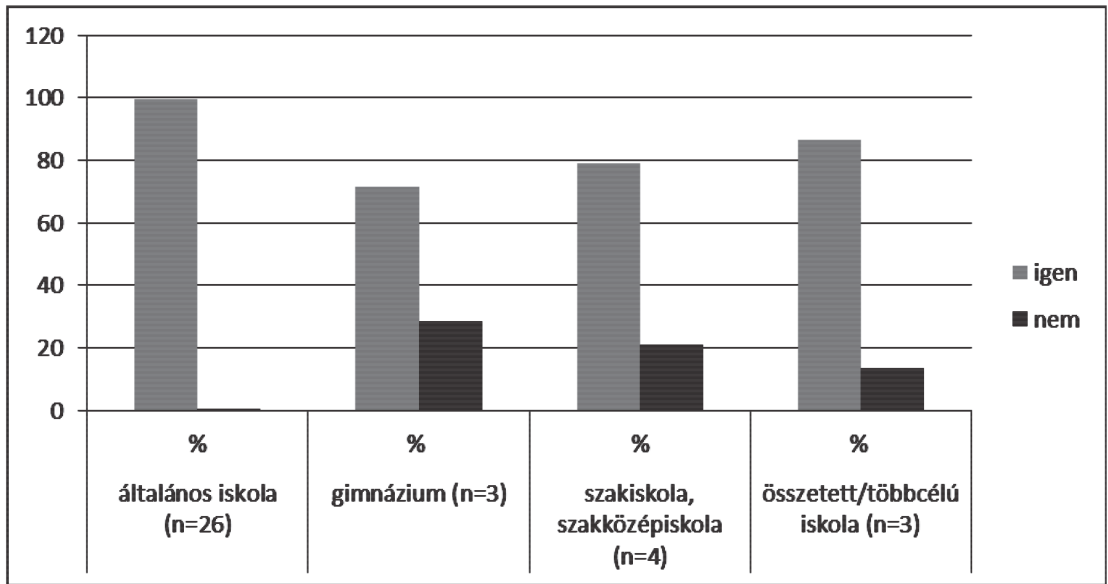

2. ábra. Integrációban való részvétel és az intézménytipus szerinti százalékos megoszlás ( $n=36)$ $(\chi 2=52,296 ; d f=3, p=0,00)$

A válaszadó pedagógusok iskoláinak túlnyomó többségében, valamennyi intézménytípusban (általános iskola, gimnázium, szakiskola és szakközépiskola, összetett/többcélú intézmény) folytatnak integrált nevelést, oktatást. Torzíthatja a képet, ezért fontosnak tartjuk megjegyezni, hogy a 36 intézményből 26 intézmény az általános iskolák közül került ki. A szakirodalom korábbi eredményeinek megfelelően jelen vizsgálat eredményei is azt támasztják alá, hogy az általános iskolák gyakorlottabbak az integrált nevelésben, oktatásban (Németh és Szilassy, 2006). Horváthné (2006) a pedagógusok tájékozatlanságával kapcsolatos vizsgálata során azt a megállapítást tette, hogy a pedagógusok nagy része nincs tisztában azzal, hogy folytat-e intézménye hivatalosan integrációt, illetve, hogy az általa tanított gyermekek között van-e, aki sajátos nevelési igényü. Tekintettel Horváthné (2006) vizsgálati eredményeire, áttekintettük az intézmények szakmai alapdokumentumait, és megállapítottuk, hogy a pedagógusok releváns információval rendelkeztek annak vonatkozásában, hogy integrál-e intézményük. Tehát a témában végzett korábbi vizsgálati eredményekhez képest (Csányi, 2000; Horváth, 2006; Fischer, 2009), a pedagógusok tájékozottsága területén eredményeink elörelépést mutatnak. 


\section{Objektív és szubjektív faktorok}

A válaszadó pedagógusok és a nevelötestület befogadó szemléletének összehasonlításából kitünik, hogy a fővárosi intézményekben vallják magukat legkevésbé befogadónak a pedagógusok. A legbefogadóbbak a községekben lévő intézményben dolgozó pedagógusok (1. 3. és 4. ábra).

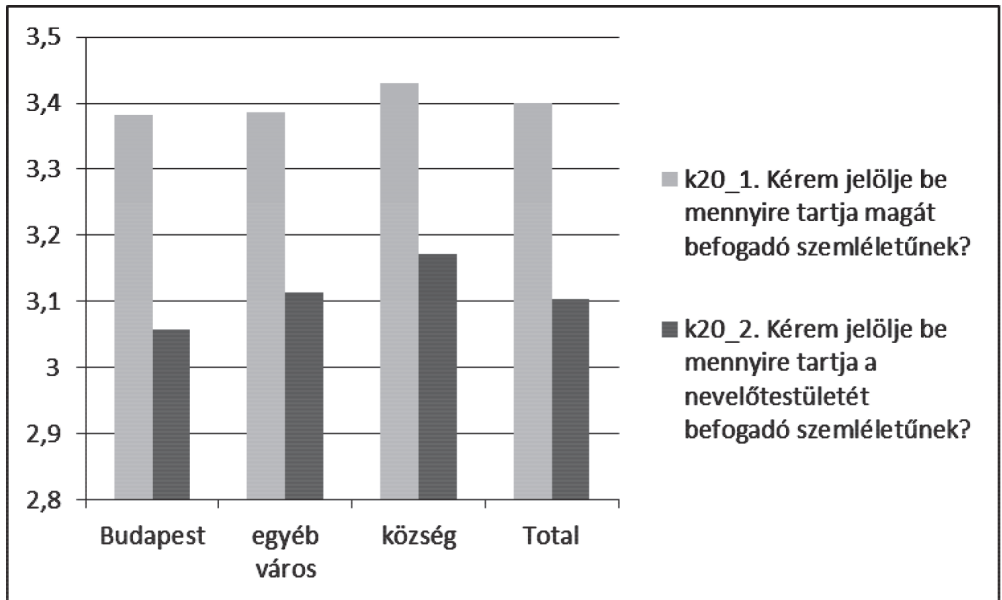

3. ábra. A pedagógusok nézetei a befogadó személetröl településtípus szerinti összehasonlitásban (arányok) $(N=36)\left(k 201\left(\chi_{2}=2,796 d f=3 p=0,042\right) ; k 202(\chi 2=3,253 d f=3, p=0,022)\right.$

Az előzetes vizsgálatok igazolták, hogy valamennyi fővárosi köznevelési intézményben van gyógypedagógus vagy utazó gyógypedagógus, ellenben a vidéki intézményben, zömmel a községekben, vannak olyan intézmények, ahol a pedagógusok saját bevallásuk szerint integráló intézményben dolgoznak, ám sem gyógypedagógusuk, sem utazó gyógypedagógusuk nincsen. Megvizsgáltuk, hogy alakul az egyes intézményekben a befogadó nevelés. Az intézmények viszonylagos homogenitást mutatnak, nem találtam kiugróan negatív intézményeket.

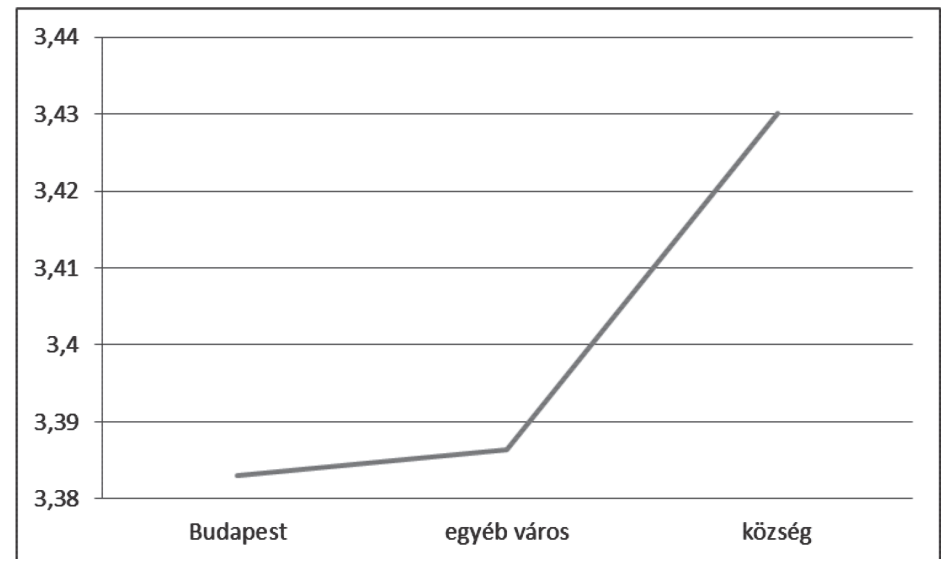

4. ábra. A befogadó szemlélet és a munkahely településtipusa szerinti összehasonlitás (átlagok) $N=315 k 20 \_1(\chi 2=2,796 d f=3 p=0,042)$ 
A pedagógusoknak a SNI tanulók integrált nevelésével szembeni negatív attitüdjének vizsgálatakor, a negatív attitüd tényezőinek feltárására fökomponens-elemzést végeztem a tényezők számának csökkentése, valamint a leírt tényezőcsoportok érvényessége miatt. A főkomponens alkotóelemeit végül a következő tényezők adták: (1) a gyógypedagógusra hárul minden probléma megoldása; (2) aránytalan terhet jelent az integráció; (3) nem tanítana szívesen bármely integrálható tanulót; (4) nem járatná szívesen gyermekét integráló osztályba; (5) nem tanítana szívesen integráló osztályba.

A negatív attitüd főkomponens az adatredukciót követően 41,827 százalékot őrzött meg információtartalmából. Valamennyi alkotóelem esetében elmondható, hogy 0,6 felettiek voltak a faktorsúlyok, a legmagasabb faktorsúly 0,746 értékü, a legalacsonyabb pedig 0,508 értékü volt.

Az egyutas varianciaelemzés (ANOVA-teszt) eredményei azt mutatják, hogy a negatív attitüd főkomponens és a településtípus között szignifikáns különbség van (ld. 5. ábra). A szórások egyezésének értéke $F=2,218$, viszonylag jó szignifikancia-szinten $p=0,019$. Az értékek közti különbségek azt mutatják, hogy a Budapesten dolgozó pedagógusok a községekben dolgozó pedagógusokhoz képest negatívabb attitüddel rendelkeznek. Eredményeink összhangban vannak Fischer (2009) kutatási eredményeivel, amely szerint a vidéken élő befogadó pedagógusok elfogadóbbak a SNI tanulókkal és az integrált nevelésükkel, oktatásukkal szemben. A kutatások szerint ennek hátterében az áll, hogy a vidéki lakosok jobban bíznak a közvetlen környezetükben lévő pedagógus kollégáikban - ennek okán feltételezhető, hogy az utazó gyógypedagógusban is -, és inkább vélik úgy, hogy azok képesek szakmailag megbirkózni az integrációból adódó nehézségekkel.

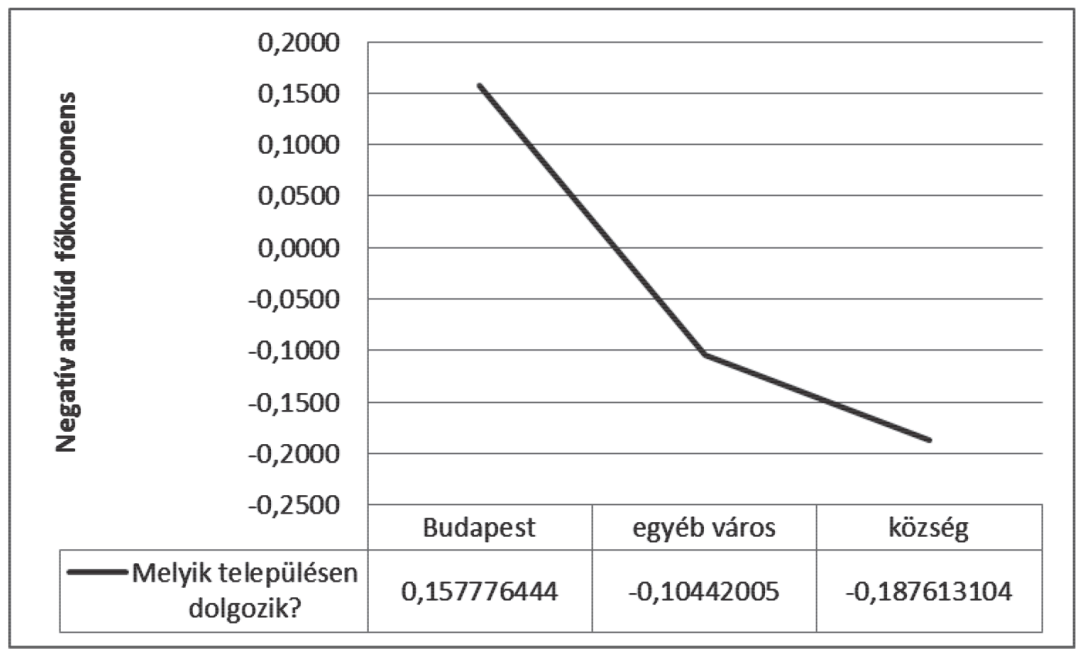

5. ábra. A vizsgálatban résztvevö pedagógusok negatív attitüdje településtípusok szerint $(F[2,218]=3,997 p=0,019 \eta 2=0,026)$

A vizsgálat során a pedagógusok nézetei a különböző sérüléstípusú tanulók integrált oktatásáról megosztó véleményeket mutat (ld. 6. ábra), hasonlóan más vizsgálatok eredményével (Illyés és Erdösi, 1986; Papp, 2001; Fischer, 2009; Némethné, 2008). 


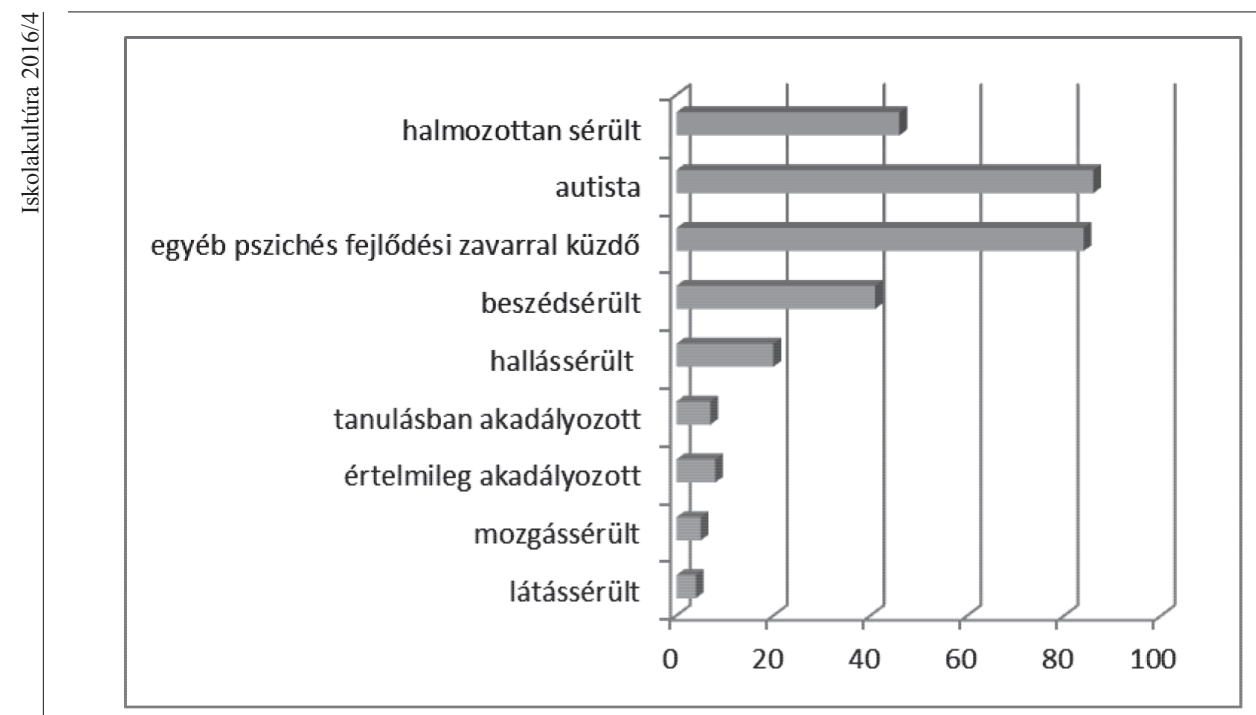

6. ábra. Eredményes oktathatóság pontszámok szerinti megoszlása (1: legeredményesebben; 9: legeredménytelenebben) $(n=301)$

\section{Hazánkban szükség lenne} olyan köznevelési intézmények létesitésére, amelyek a pszichiátriai osztályok mellett fogadnák az antiszociális személyiségzavarral veszélyeztetett tanulókat. A jelenlegi kórházi gyakorlat szerint nem állitanak ki 18 év

alatti tanulóknak a fentebb megnevezett betegségre utaló kódot, ezen gyermekek gyógyitásának nincs orvosi protokollja.

Ennek következtében jelenleg nem biztositott számukra sem a terápiás eljárás, sem a megfeleló intézményi elhelyezés. Ezen tanulók nagy számban kerülnek be mind az integráló intézményekbe, mind pedig a speciális intézményekbe.
Az eredmények azt mutatják, hogy a válaszadó pedagógusok a SNI tanulók közül a legeredményesebben oktathatónak a látássérült, ezt követően a mozgássérült, majd a tanulásban akadályozott tanulókat tartják. Illyés és Erdősi (1986), valamint Fischer (2009) korábbi vizsgálati eredményei ezzel szemben azt találták, hogy a befogadó pedagógusok körében legkevésbé elfogadottak a középsúlyosan, illetve súlyosan értelmi fogyatékos tanulók, illetve személyek. Ezzel szemben jelen vizsgálat szerint a válaszadó pedagógusok a legkevésbé eredményesen oktathatónak a SNI tanulók közül az autista ${ }^{4}$ és az egyéb pszichés fejlődési zavarral ${ }^{5}$ küzdő tanulókat tartják. Ennek oki hátterében valószínüsíthetően az áll, hogy egyrészt az autista tanulók integrált nevelése-oktatása speciális szakismerettel rendelkezö szakembereket kíván meg, továbbá speciális tárgyi felszereltséget a teljes befogadó intézményben. Magyarországon nagyon kevés az autista tanulók ellátására felkészített szakember, mivel csak néhány éve indult el az Autizmus spektrum pedagógiája szakirány, az országban egyedülálló módon az ELTE Bárczi Gusztáv Gyógypedagógiai Karán. Másrészt a kapott eredményt indokolhatja a diagnosztikai és az intézményi gyakorlat, 
amely szerint autista vagy egyéb pszichés fejlődési zavarral (ezen belül súlyos figyelem- és magatartási szabályozási zavarral) küzdő tanulók kategóriájába sorolják a súlyos pszichiátriai eseteket.

Hazánkban szükség lenne olyan köznevelési intézmények létesítésére, amelyek a pszichiátriai osztályok mellett fogadnák az antiszociális személyiségzavarral veszélyeztetett tanulókat. A jelenlegi kórházi gyakorlat szerint nem állítanak ki 18 év alatti tanulóknak a fentebb megnevezett betegségre utaló kódot, ezen gyermekek gyógyításának nincs orvosi protokollja. Ennek következtében jelenleg nem biztosított számukra sem a terápiás eljárás, sem a megfelelő intézményi elhelyezés. Ezen tanulók nagy számban kerülnek be mind az integráló intézményekbe, mind pedig a speciális intézményekbe.

A változórendszer struktúrájának és az adatok hierarchikus szerveződésének vizsgálatát lineáris regresszióanalízissel végeztük el. A lineáris regresszióanalízis elsődleges célja az volt, hogy statisztikai úton a kérdőívekből meghatározzuk azokat a dimenziókat, amelyekkel ma hazánkban a pedagógusok negatív attitüdje jellemezhető, esetleg mérhető. A bemutatott elemzések során a független változókat intervallumváltozóknak tekintettük; amennyiben a függő változók nominálisak vagy ordinálisak voltak, akkor indikátorváltozókká ('dummy') alakítottuk őket, hogy alkalmassá tegyük a regressziós eljárás alkalmazásához. A függő változóról minden esetben feltételeztük, hogy az folytonos eloszlásból származik.

A lineáris regresszióanalízis során a pedagógusok negatív attitüdjét befolyásoló tényezők összehasonlítására került sor demográfiai, objektív és szubjektív háttérváltozókkal. Az 1. táblázatban csak a Standard Béta szignifikáns eredményeit tüntettük fel.

\section{1. táblázat. A pedagógusok negativ attitüdjét befolyásoló objektív és szubjektív tényezök összehasonlitása}

\begin{tabular}{|l|c|c|}
\hline & B & sztenderdizált béta-értékek \\
\hline (Konstans) & 1,776 & 3,384 \\
\hline k2. Neme (1 = férfi, 2 = nö) & $-0,447$ & $-2,534$ \\
\hline k10. Hány iskolai/tanitási év gyakorlata van? & & \\
\hline életkor (év) & & \\
\hline & & \\
\hline Szzemélyes kapcsolat fogyatékossággal élökkel (1 = van, 0= nincs) & $-0,363$ & $-2,825$ \\
\hline Speciális szakismeret SNI oktatásához (1 = van, 0 = nincs) & $-0,282$ & $-2,327$ \\
\hline SNI diákokkal foglalkozott vagy foglalkozik-e (1 = igen, 0 = nem) (k16) & $-0,502$ & $-3,286$ \\
\hline & & \\
\hline Településtípus: föváros (referencia: község) & 0,4 & 3,065 \\
\hline Településtípus: egyéb város (referencia: község) & & \\
\hline & & \\
\hline Intézménytípus: gimnázium, szakközépiskola (referenciakategória: általános iskola) & $-0,427$ & \\
\hline Intézménytípus: szakiskola (referenciakategória: általános iskola) & & \\
\hline Intézménytípus: többcélú intézmény (referenciakategória: általános iskola) & & \\
\hline
\end{tabular}

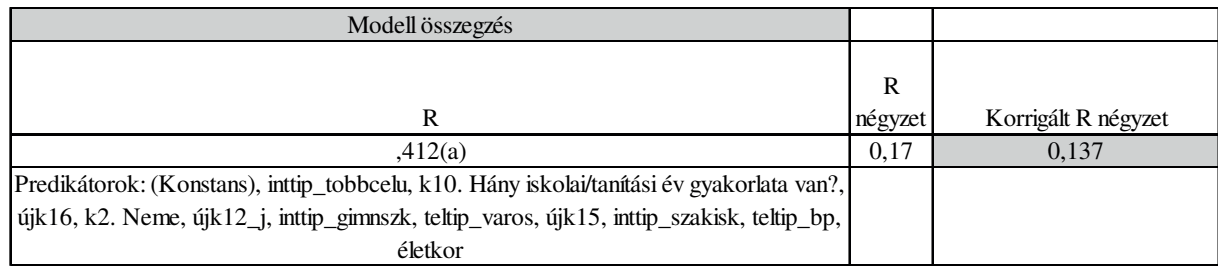

A regressziós modell eredményei azt mutatják, hogy a legerősebben ható tényező a modellben az volt, hogy a pedagógus foglalkozott-e vagy foglalkozik-e SNI tanulóval. Tehát ennek a tényezőnek volt a legnagyobb hatása a kimeneti változóra. A negatív érték azt jelzi, hogy csökkentő hatással bír az elöítéletességre, ha a pedagógusnak van 
tapasztalata SNI tanulók nevelésében, oktatásában. A második erősen ható tényező a településtípus volt, amelynek érdekes hatását találtam. A településtípusokat a községhez hasonlítva megállapíthatjuk, hogy a községek és a városok nem térnek el egymástól. A főváros esetében erős pozitív értéket láthatunk. A fővárosban dolgozó pedagógusok tehát a községben élőkhöz képest elöítéletesebbek. A sorrendet tekintve harmadikként markáns változónak bizonyult a fogyatékossággal élő személyekkel való személyes kapcsolat, amely független a tanári pálya tapasztalatától. A személyes kapcsolat a fogyatékossággal élő személyekkel igazolhatóan csökkenti az elöítéletességet. A negyedikként ható tényező a társadalmi nem volt. A nők elöítéletességét a férfiakhoz képest vizsgálva azt találtuk, hogy a nők kevésbé előítéletesek, mint a férfiak. Ötödik hatótényező a speciális szakismeret volt, amely csökkenti az elöítéletességet. Végezetül, hatodik tényezőként a településtípus hatását vizsgáltuk: a regressziós modell eredménye szerint az általános iskolákhoz képest a szakiskolák és a többcélú intézmények között nics szignifikáns különbség. A negatív együtthatóból azonban látható, hogy a gimnáziumok és a szakközépiskolák kevésbé elöítéletesek. Továbbá az életkor és az iskolai végzettség tekintetében sem találtunk szignifikanciát. Ez utóbbi a modell sajátossága.

A regressziós modell által megmagyarázott variancia a teljes variancia 13,7 százaléka, tehát a modell ennyiben adja vissza az eredeti információtartalmat, amely kifejezettem jónak számít.

\section{Összegzés, következtetések}

Tanulmányunkban arra vállalkoztunk, hogy bemutatjuk a pedagógusok SNI tanulókkal szembeni elöítéletes attitüdjét befolyásoló tényezőket, egy Közép-magyarországi régióban végzett kérdőíves kutatás eredményei alapján. Feltételeztük, hogy az elfogadó attitüdnek összetettsége okán társadalmi és egyéni szintü magyarázatai is vannak. Két dimenzióban mértük a SNI tanulókkal és integrált nevelésükkel szembeni viszonyulást: objektív tényezők (nem, életkor, iskolai végzettség, intézménytípus) és szubjektív tényezők (munkahely településtípusa, személyes kapcsolat, speciális szakismeret. integrál-e).

Elsố hipotézisünk, mely szerint a pedagógusok nem rendelkeznek kelló, különösen nem speciális ismeretekkel a fogyatékosságról és a SNI tanulók neveléséról-oktatásáról, elemzésünk alapján igazolódni látszik. A szakirodalom korábbi eredményeivel (ld. Szegó, 2008; Miles, 2000; Némethné, 2009) összhangban a vizsgálat során kirajzolódott az az összefüggés, hogy a SNI tanulók nevelése-oktatása során szerzett tapasztalat csökkenti az elóitéletességet.
$\mathrm{Az}$ eredmények értelmezéséhez lássuk a hipotézisek igazolását! Első hipotézisünk, mely szerint a pedagógusok nem rendelkeznek kellö, különösen nem speciális ismeretekkel a fogyatékosságról és a SNI tanulók neveléséről-oktatásáról, elemzésünk alapján igazolódni látszik. A szakirodalom korábbi eredményeivel (1d. Szegö, 2008; Miles, 2000; Némethné, 2009) összhangban a vizsgálat során kirajzolódott az az összefüggés, hogy a SNI tanulók nevelése-oktatása során szerzett tapasztalat csökkenti az elöítéletességet. A következő hipotézis, amely szerint a Pest megyében dolgozó pedagógusok pozitívabb attitüddel rendelkeznek az integrált neveléssel kapcsolatban, mint a fövárosban dolgozók, beigazolódott. A fővárosban dolgozó pedagógusok negatívabb attitüdjének hátterében megítélésünk szerint korábbi vizsgálati eredményektől eltérően nem csak az áll, hogy a községekben dolgozó pedagó- 
gusok között jobbak a személyközi és a szakmai kapcsolatok (Fischer, 2009), hanem az is fontos tényező lehet, hogy a községekben dolgozó pedagógusok, bár speciális szakismerettel nem rendelkeznek, ellenben nagy tapasztalattal bírnak a különleges bánásmódot igénylő tanulók differenciált oktatásáról. Kirajzolódott továbbá a hipotéziseken túl egy lényeges eredmény a vizsgálatból. Az intézmények közti homogenitás a befogadó szemléletben azt feltételezi, hogy az intézményi felkészülési szint sokat javult az elmúlt években. A harmadik felvetésünk, miszerint az értelmileg akadályozott tanulókkal szemben a legalacsonyabb az elfogadás a pedagógusok körében, a vizsgálat során nem nyert igazolást. Eredményeink azt mutatják, hogy az autista és az egyéb pszichés zavarral rendelkező tanulók elfogadása okozza számukra a legnagyobb kihívást. A negyedik hipotézis igazolódott: a negatív attitűd társadalmi nemtől független, és befolyásolják az ismeretek.

Áttekintve a témában (átlagosan 5 évvel ezelőtt) végzett korábbi kutatások s a jelen vizsgálat eredményeit (ld. 2. táblázat) megállapítható, hogy az életkor és a pályán eltöltött évek száma egyre kevésbé befolyásolja a pedagógusok szolidaritását, ellenben a tapasztalat a SNI tanulók integrált nevelésében, oktatásában, továbbá a speciális szakismeret döntő jelentőségü az attitüd formálásában.

A kutatási eredmények sorra azt igazolták, hogy az intézményi szinteken felfelé haladva csökken a pedagógusok befogadó kedve. Jelen vizsgálatban a középfokú intézmények alulreprezentáltsága okán nem volt lehetőségem ezt a tézist megvizsgálni, azonban fontosnak tartanám ezirányú kutatások elvégzését. Az elmúlt évek oktatáspolitikai szándékának köszönhetően az állami fenntartó valamennyi településen törekszik arra, hogy a különböző sérüléstípusú tanulók számára legyen olyan köznevelési intézmény (az összes iskolafokon), amely biztosítja a SNI tanulók integrált nevelését, oktatását. Érdemes lenne továbbá vizsgálni a pedagógusok felkészítését, képzését az SNI tanulók integrált nevelésére, oktatására. Fontos lenne a többségi pedagógusok és az utazó gyógypedagógusok szakmaközi együttmüködésének célzott vizsgálata is.

\section{Irodalomjegyzék}

Antonak, R. F. és Livneh, H. (1988): The measurement of attitudes toward people with disabilities. Methods, psychometrics and scales. Charles C. Thomas Publisher, Springfield.

Atkinson, T. (1998): Társadalmi kirekesztődés, szegénység és munkanélküliség. Esély, 9. 4. sz. 3-18.

Billédi Katalin (2008): Inklúziv nevelés-elöitéletmentes attitüd-tolerancia. SuliNova Kht., Budapest

Commission (2011): A Bizottság közleménye az európai parlamentnek, a Tanácsnak, az Európai Gazdasági és Szociális Bizottságnak és a Régiók Bizottságának. Comission Bruxelles. 2013. 12. 21-i megtekintés, http://ec.europa.eu/education/school-education/ doc/earlycom_hu.pdf

Csányi Yvonne (1993): Integrált fejlesztés a kutatás szintjén. In: Csányi Yvonne (szerk.): Együttnevelés Speciális igényü tanulók az iskolában. Az integrált fejlesztés lehetőségei. ALTERN füzetek. 5. Iskolafejlesztési Alapítvány - OKI Iskolafejlesztési Központ, Budapest. 22-28.
Csányi Yvonne (2000): A speciális nevelési szükségletű gyermekek és fiatalok integrált nevelése-oktatása. In: Illyés Sándor (szerk.): Gyógypedagógiai alapismeretek. ELTE BGGYTF, Budapest. 377-407.

Csapó Benő (2002): Az iskolai szelekció hatásának elemzése a képességek fejlődésének számítógépes szimulációja segítségével. Magyar Pszichológiai Szemle, 57. 1. sz. 211-227. DOI: 10.1556/ mpszle.57.2002.1.10

Erős Gábor és Gárdos Judit (2007). Az előítélet kutatások bírálatához. Educatio, 16. 1. sz. 17-57.

European Report (2011): Intolerance, Prejudice and Discrimination. Friedrich Ebert Stiftung, Berlin. 2014. 08. 10-i megtekintés, http://pub.uni-bielefeld. de/luur/download?func $=$ downloadFile \&recordOId $=2$ 018626\& fileOId $=2269239$

Falus Iván és Ollé János (2000): Statisztikai módszerek pedagógusok számára. OKKER Kiadó Kft., Budapest. 
Fischer Gabriella (2009): Az integrációval kapcsolatos attitüdök kutatása. Gyógypedagógiai Szemle, 39. 4. sz. 254-268.

Forlin, C., Loreman, T., Sharma, U. és Earle, C. (2009): Demographic differences in changing preservice teachers' attitudes, sentiments and concerns about inclusive education. The International Journal of Inclusive Education, 13. 2. sz. 195-209.

DOI: $10.1080 / 13603110701365356$

Fuller, M., Bradley, A. és Healey, M. (2004): Incorporating disabled students within an inclusive higher education environment. Disability and Society, 19. 5. sz. $455-468$

DOI: $10.1080 / 0968759042000235307$

Gaál Sándorné (2007): Az inklúzió fogalma, tartalma. In: Girasek János (szerk.): A tanulók hatékony megismerése. SuliNova Közoktatás-fejlesztési és Pedagógus-továbbképzési Kht., Budapest.

Holloway, S. (2001): The Experience of Higher Education from the Perspective of Disabled Students. Disability and Society, 16. 4. sz. 597-615. DOI: 10.1080/09687590120059568

Horváth György (2004): A kérdöives módszer. Müszaki Könyvkiadó, Budapest.

Horváthné Moldvay Ilona (2006): Attitűdvizsgálat pedagógusok körében az integrált nevelésröl. Iskolakultúra, 16. 10. sz. 81-97.

Illyés Sándor és Mérei Vera (1975): Elfogadás és elutasítás az épek fogyatékosokhoz füződő társas kapcsolatában. In: A Bárczi Gusztáv Gyógypedagógiai Tanárképzö Főiskola Évkönyve IX. 225-235.

Illyés Sándor és Erdősi Sándor (1986): Az épek fogyatékosképe és a fogyatékosokhoz való viszonya. In: Társadalmi beilleszkedési zavarok. Tájékoztató bulletin VI. MSZMP KB TTII, Budapest. 3-57.

Könczei Miklós (2009): A fogyatékosügy nemzetközi és hazai története. ELTE BGGYFK, Budapest.

Központi Statisztikai Hivatal (2013): A 2011. évi népszámlálás. 3. országos adatok. Budapest.

Laki Tamásné (2010): Az együttnevelés mühelye. A RAMPA integrációs programsorozatának tapasztalatai. Együttnevelés Mühelye, 60. 1-2. sz. 73-93.

Larrivee, B., Cook, L. (1979): Mainstreaming: a study of the variables affecting teacher attitude. Journal of Special Education, 13. 3. sz. 315-324. DOI: 10.1177/002246697901300310

Leyers Y., Abrams, P. D. (1983): A shift to the positive: An effective programme for changing preservice teachers' attitudes toward the disabled. Educational Review, 35. 1. sz. 35-43. DOI: $10.1080 / 0013191830350104$
Likert, R. (1932): A Technique for the Measurement of Attitudes. Archives of Psychology, New York.

Meijer, C. J. W. (2001): Inclusive Education and Effective Classroom. Practices. European Agency for Development in Special Needs Education, Middelfart.

Miles, S. (2000): Overcoming Resource Barriers: the challenge of implementing inclusive education in rural areas. Symposium on Development Policy. Gustav Stresemann Institute, Bonn, Germany, October 27-29.

Murányi István (2006): Identitás és előitélet. Új Mandátum Könyvkiadó, Budapest.

Németh Szilvia és Szilassy Eszter (2006): „Tegyük akadálymentessé magunkat!" Sajátos nevelési igényü tanulók és az integrált oktatás Magyarországon. Regio, 17. 1. sz. $102-145$.

Némethné Tóth Ágnes (2008): Körkép a befogadó nevelésröl Európán innen és túl. Fejlesztö Pedagógia, 19. 6. sz. 20-25.

Némethné Tóth Ágnes (2009): Tanári attitüdök és inklúzív nevelés. Magyar Pedagógia, 109. 2. sz. 105-120.

OECD (2012): Education at a Glance 2012 Highlights. OECD Publishing. 2013. 12. 19-i megtekintés, DOI: 10.1787/eag_highlights-2012-en

Papp Gabriella (2002): Tanulásban akadályozott gyermekek iskolai integrációja a szakemberek közötti kooperáció tükrében. Magyar Pedagógia, 102. 2. sz. $159-178$

Perlusz Andrea (2008): Látássérültek iskoláztatása és társadalmi integrációja. In: Bánfalvy Csaba (szerk.): Az integrációs cunami - Tanulmányok a fogyatékos emberek iskolai és társadalmi integrációjáról. ELTE BGGYFK - ELTE Eötvös Kiadó, Budapest. 113 -129 .

Torda Ágnes és Perlusz Andrea (2010): Pedagógusképzési programok utóélete - Egy hatásértékelő tanulmány tükrében. Felsöoktatási Mühely, 2. sz. 125-137.

Pető Ildikó és Ceglédi Tímea (2012): A pedagógusok SNI-vel szembeni attitüdje SACIE-vel mérve. A Sentiments, Attitudes and Concerns about Inclusive Education Scale (SACIE). Iskolakultúra, 22. 11. sz. 66-82.

Pongrácz Kornélia (2013): Többségi általános iskolások sajátos nevelési igényű gyermekekkel szembeni attitüdjének vizsgálata. Gyógypedagógiai Szemle, 41. 3. sz. 197-207.

Pusztai Gabriella és Szabó Diána (2014): Felsőoktatási hallgatók és fogyatékossággal élő társaik. Kapocs, 13. 4. sz. 23-36. 
Réti Csilla és Csányi Yvonne (1997): Gyakorló pedagógusok és leendő tanítók attitüdjének felmérése az integráció témájában. Gyógypedagógiai Szemle, $\mathbf{9 8 .}$ 2. sz. 81-89.

Rye, H. (1993): Integrált oktatás - bevezetés a közösségbe. In: Csányi Yvonne (szerk.): Együttnevelés. Speciális igényü tanulók az iskolában. Iskolafejlesztési Alapítvány - OKI, Budapest.

Sharma, U., Forlin, C. és Loreman, T. (2008): Impact of training on pre-service teachers' attitudes and concerns about inclusive education and sentiments about persons with disabilities. Disability and Society, 23. 7. sz. 773-785. 2013. 08. 09-i megtekintés, http://www.informaworld.com/smpp/content $\sim$ content $=\mathrm{a} 906329656 \sim \mathrm{db}=\mathrm{a} 1 \mathrm{j} \sim \mathrm{ju}$ mptype $=\mathrm{rss}$. DOI: $10.1080 / 09687590802469271$

Strobe, W. és Jonas, K. (1995): Az attitüdök megváltoztatásának stratégiái. In: Hewsrone, M., Stroebe, W., Codol, J. P. és Stephenson, G. M. (szerk.): Szociálpszichológia. Közgazdasági és Jogi Könyvkiadó, Budapest. 188-219.

Szegö Ágnes (2004): A pedagógusok attitüdje az integrált oktatással kapcsolatban. Szakdolgozat. ELTE, Budapest.
Szegő Ágnes (2008): Pedagógusok attitűdje az integrált oktatással kapcsolatban. Alkalmazott pszichológia, 10. 3-4. sz. 21-34.

Szekeres Ágota (2012): Integráltan tanuló, enyhén értelmi fogyatékos gyermekek szociális helyzetének felmérése szociometria segítségével. Iskolakultúra, 22. 11. sz. 3-23.

Takács Judit (2007): Elöítélet és megkülönböztetés az iskolában. Educatio, 16. 1. sz. 67-83.

Tavares, W. (2011): An evaluation of the kids are kids disability awareness program: Increasing social inclusion among children with physical disabilities. Journal of Social Work in Disability \& Rehabilitation, 10.1.sz. 25-35. DOI: 10.1080/1536710x.2011.546296

Thurstone, L. L. (1931): Rank order as a psychological method. Journal of Experimental Psychology, 14. sz. 187-201.

Újfalussy Rita Benedikta (2014): A felnövekvő értelmiség sérült emberekhez való viszonya. Gyógypedagógiai Szemle, 42. 1. sz. 48-62.

\section{Jegyzetek}

${ }^{1}$ A kérdőív e-mailen megkapható a szabo.diana86@ gmail.com címen.

${ }^{2}$ Az egyik kérdőív az Antonak és Livneh (1988) által megalkotott ATDP (Attitudes Toward Disabled Persons) magyarra fordított változata, a másik kérdőív Larrivee és Cook (1979) ORM (Opinions Relative to Mainstreaming) kérdőívének magyarra fordított, lektorált változata (Szegö, 2004).

${ }^{3}$ Az OECD (2012) kutatásában részt vevő országokban, az alsó középfokon tanítók 70 százaléka nő, ez az arány Magyarországon 77 százalék. A pedagógus pálya elnőiesedése mellett szintén nem csak hazai probléma, hogy a pedagógusok életkor szerinti összetétele egyre inkább eltolódik az idősebb korosztály irányába. Az OECD (2012) kutatás adatai szerint a vizsgálatban részt vevő pedagógusok többsége 40 év feletti, kétszer annyian vannak az 50 év feletti pedagógusok, mint a 30 év alattiak. Ezen adatok elörevetítik, hogy a legtöbb országban hamarosan pedagógushiánnyal kell számolni. Magyarország adatai ezen a téren megfelelnek az OECD 2012-es kutatás átlagának, a pedagógusok 12 százaléka 30 év alatti és 28 százalékuk 50 év feletti volt

${ }^{4} \mathrm{Az}$ autizmus spektrum zavar (ASD; Autism Spectrum Disorder) fejlődés neurológiai zavar, a központi idegrendszer stabil sérüléses állapotának az eredménye, a következményes, a viselkedés és a fejlödés sajátosságai alapján meghatározható komplex viselkedéses szindróma. Következményeként három területen jelenik meg minőségi károsodás: a kommunikációban, a szociális viselkedés, valamint a rugalmas viselkedésszervezés terén, az állapotot e készségek fejlődési devianciája és késése jellemzi (ld. bővebben: Egészségügyi Minisztérium szakmai irányelve 2005.)

${ }^{5}$ Egyéb pszichés zavarral küzdők, a súlyos tanulási zavarral küzdő SNI tanulók csoportjába tartoznak, akiknek valamilyen súlyos és tartós részképesség gyengesége miatt iskolai tanulmányaikat sikertelenül teljesítik. Ide sorolják a diszlexiásokat, a diszkalkuliásokat, a diszgráfiásokat és a súlyos figyelem- és magatartási szabályozás zavarával küzdőket is (ld. bővebben: Gyarmaty, 2007). 


\section{Melléklet}

2. táblázat. A témában végzett kutatási eredmények összehasonlitása

\begin{tabular}{|c|c|c|}
\hline $\begin{array}{l}\text { SZAKIRODALOM } \\
\text { EREDMÉNYEI }\end{array}$ & & $\begin{array}{c}\text { JELEN VIZSGÁLAT } \\
\text { EREDMÉNYEI }\end{array}$ \\
\hline \multicolumn{3}{|c|}{ DEMOGRÁFIAI TÉNYEZŐK } \\
\hline nők, ill. nincs & társadalmi nem & nők \\
\hline $\begin{array}{c}\text { „idősebbek” } \\
\text { elöítéletesebbek }\end{array}$ & életkor & nincs \\
\hline változó & iskolai végzettség & nincs \\
\hline van & pályán eltöltött évek & nincs \\
\hline \multicolumn{3}{|c|}{ OBJEKTÍVÉS SZUBJEKTÍVTÉNYEZŐK } \\
\hline van & személyes kapcsolat & van \\
\hline van & $\begin{array}{c}\text { ismeret } \\
\text { (fogyatékosságról, } \\
\text { integrációról) }\end{array}$ & $\begin{array}{c}\text { speciális szakismeret } \\
\text { van }\end{array}$ \\
\hline változó & $\begin{array}{l}\text { tapasztalat SNI } \\
\text { tanulókkal }\end{array}$ & van \\
\hline- & $\begin{array}{l}\text { településtípus } \\
\text { (város, község) }\end{array}$ & $\begin{array}{l}\text { K-M Régiót nem } \\
\text { vizsgálták }\end{array}$ \\
\hline van & intézménytípus & változó \\
\hline
\end{tabular}

